\title{
Assessment of Training Needs Among Dairy Cattle Farmers in Oyo State, Nigeria
}

\author{
Popoola Moshood Abiola ${ }^{1}$, Ajani Adedayo Olumuyiwa ${ }^{1}$, Olaniyi Taiwo Anne ${ }^{1}$, Lamidi Lukuman Olalekan ${ }^{1}$, \\ Hamzat Olatunji Alabi ${ }^{1}$, Taiwo Oludare Dominic ${ }^{1}$, Adesanlu Ayorinde Afolabi ${ }^{1}$ \& Amao Adepeju Alaba ${ }^{1}$ \\ ${ }^{1}$ Federal College of Animal Health and Production Technology, Moor Plantation, Ibadan, Nigeria \\ Correspondence: Popoola Moshood Abiola, Federal College of Animal Health and Production Technology, Moor \\ Plantation, Ibadan, Nigeria. E-mail: herbyolar@gmail.com
}

Received: April 21, 2020 Accepted: May 10, 2020 Online Published: May 15, 2020

\begin{abstract}
The training needs of dairy cattle farmers in Oyo state, Nigeria were assessed. A well-structured interview schedule was used to obtain information from 123 respondents. Data were collected on socio-economic characteristics of the respondents, their dairy cattle production enterprises and their training needs which were ascertained in six major areas of cattle production: feeding, breeding, healthcare, housing and management, marketing and finance, product preparation and processing. Data were subjected to descriptive statistics and regression analysis using SPPS (V.21). Results revealed that most (30.1\%) of the respondents were $24-29$ years old, married, were male, had no formal education. Results also revealed that more than $90 \%$ of dairy cattle farmers perceived the training needs in feeding as most important. The training index in dairy farming indicated that majority $(91.8 \%)$ of the farmers needed to be trained more on dairy cattle production and management. Based on the result of this study, it was concluded that breeding, feeding and health care were perceived as the "most needed" training by the respondents. Although, training need in marketing and finance, milk preparation and processing, as well as housing and management were also perceived as important. Furthermore age, sex, marital status, religion, education level, source of flock, purpose of production and breeds of cattle had a direct effect on training needs of the respondent while occupation, household, herd size, had an indirect effect on training need of the respondents.
\end{abstract}

Keywords: Cattle, dairy farmers, production, training index, training needs

\section{Introduction}

Livestock industry accounts for 3.8 percent of the Gross Domestic Product (GDP); with the dairy sub-sector contributing 30 percent of this output (Njombe et al., 2010). Dairy sub-sector contribution is not only limited to its share to total GDP but also play other important roles such as improving food security and welfare, creating employment, generates reliable income to meet household livelihoods (Somda et al., 2005). FAO (2010) reported that dairy industry in Nigeria produces an estimate of 450, 000 tons of milk per annum. This production has been found to be inadequate to satisfy the dairy demands of Nigerians, FAO (2010), this is because the genotype of the African breeds of cattle can only produce an average milk of 1.27 litres per cow per day during the wet season and less than 0.36 during dry season (Yuan et al., 2010), whereas their counterparts in the European and American countries produce an average of 25 litres per day (Mallau-Aduli, et al., 2009).

Nigeria is one of the leading countries in cattle production in Sub-Saharan Africa. Tibi and Aphunu (2010) reported that the country had over 14.73 million cattle consisting of 1.47 million milking cows and 13.26 million beef cattle. Less than $1 \%$ of this population is managed commercially, while about $99 \%$ is managed traditionally. Under the traditional system, there is the use of indigenous methods in all aspects of cattle production including health management (Mafimisebi et al. 2012). This tilt towards traditional management continues to have grave implications for commercialization of the production of cattle and cattle products as well as their prices in Nigeria (Abubakar and Garba, 2004).

A farmer being a rational decision maker normally strives for a better standard of living and seeks ways of adopting new technologies to accomplish the set goals (Murai and Singh, 2011). Training in agricultural related practice improves farmers' ability to acquire accurate information, evaluate new production processes, use improved husbandry practices and these benefits translate into adoption if a set of enabling factors and conditions exists to train the farmers (Adesina and Zinnah, 1993). Effective dissemination of improved dairy husbandry practices 
through training is an important strategy for increasing adoption; it creates awareness and competence in the target audience about innovations (Thapa, 2003).

Farmers' training is a process of imparting specific skills to farmers that let them better perform their farm production activities and become more competent and proficient in doing their farm work (Imaita, 2013). Many studies have demonstrated high economic returns to investment in improved husbandry practices through extension and training despite the difficulty of isolating its impact on agricultural productivity and growth from other factors (Khan et al., 2009). According to FAO (2011) farmers' training aims at communicating information, knowledge and skills, replacing old attitudes by new ones, exchanging opinions and experiences and reducing the amount of perceived complexity in a technology thereby creating a desired change. Effective dissemination of improved dairy husbandry practices through training is an important strategy for increasing adoption; it creates awareness and competence in the target audience about innovations (Thapa, 2003).

According to Rivara et al (2004), good management practices in terms of adequate nutrition, disease prevention, control and breeding are essential for improved dairy production. Although the productivity of dairy in Nigeria is low there is ample opportunity for improvement which can be achieved through extension education and training of dairy farmers. However, such extension education and training can only be effective if the training needs of the dairy farmers are properly identified. Thus, this study sought to assess training needs among dairy cattle farmers in Oyo state, Nigeria.

\section{Method}

The study was conducted in Oyo State; it is located in the South-West geopolitical zone of Nigeria. It consists of 33 Local Government Areas (LGAs). The State covers a land area of 28,454 square kilometers with a population of 5.6 million people NPC (2006) with climatic conditions that favour agriculture. The wet season is from April to October, with the mean temperature of $27^{\circ} \mathrm{C}$. The dry season is between November and March. The mean annual rainfall is $1,194 \mathrm{~mm}$ in the North and $1,264 \mathrm{~mm}$ in the South. Within Oyo state, the Zebu cattle (White Fulani and other Zebu breeds) are herded in the lowlands, amidst land progressively used for crop production. The major crops grown in the state include cassava, maize, yam, sorghum, cocoa, cocoyam, melon, peppers, soybean and okro; major livestock reared in the state include; cattle, sheep, goat and poultry.

A two-stage sampling procedure was adopted for this study. The first stage involved purposive selection of nine local government areas (LGAs) where dairy farmers were predominant in the State. The areas are Ido, Iseyin, Lagelu, Saki, East, Saki West, Ibarapa East, Oyo West Itesiwaju, and Ogbomosho North. List of these farmers was generated in each of these LGA from their Associations (Miyyeti Allah Cattle Breeders Association MACBAN). The second stage involved random selection of at least 10 members from the list in each of the LGA to give 123 respondents. A well-structured interview schedule was used to obtain information from these respondents. Data were collected on socio-economic characteristics of the respondents, their dairy cattle production enterprises and training needs of farmers which were ascertained in six major areas viz., feeding, breeding, healthcare, housing and management, marketing and finance, product preparation and processing,. The areas were assessed on three point's continuum which were: most important, important, and least important, with the scores of 3, 2 and 1, respectively as reported by Balaraju et al., (2004). The major areas were further classified into sub-areas and the training needs of dairy farmers were ascertained at three point continuum viz., most needed, needed and least needed, with the score of 3, 2 and 1, respectively (Balaraju et al., 2004).

Frequency and percentage for each major area were calculated and ranking was done for each category based on the total weighted mean score. The summation of scores achieved by the respondents constituted the level of perceived training needs. The extent of training needs was calculated based on the "Training Need Index (TNI)" formula which was individually calculated on each sub-area. The summation of scores was further categorized as low, medium and high level training needs as perceived by the farmers. The total weighted mean score and TNI were calculated using the following formula:

Total weighed mean score $($ TWMS $)=\quad$ Total score obtained by each major area

$$
\text { Total number of respondent }
$$

Training needs index $(\mathrm{TNI})=$

Total obtained score

x 100

Data were subjected to Descriptive Statistics (Mean, Frequency and Percentage) and Regression Analysis using SPSS (V.21). 


\section{Results}

Table 1 shows the socio economic characteristics of dairy cattle farmers. Results revealed that most of the respondents were within the age range of $24-29$ years (30.1\%), followed by those within range of $30-34$ years $(19.5 \%)$ and the least were those who were within age of $20-24$ years $(18.7 \%)$ and those who were older than 35 years $(8.9 \%)$. Mean age of the respondents was 34.7 years. Majority of the respondents were male $(51.2 \%)$ while $48.8 \%$ were females. Most of them were married (56.7\%). All of the respondents were Muslims with most (74\%) having no formal education, $18.7 \%$ of them had primary education, few $(6.5 \%)$ of the respondents had secondary education. The result of household size of respondents showed that majority of the respondents had household size between 6-9 members (47.2\%), 26.0\% had household size of between 2-5 members, while 18.7\% had household size of between 10-13 members, the least was obtained in those with household size greater than 13 members (8.1\%). The mean household size was 17 . The result further revealed that majority $(52.0 \%)$ of the respondents earned more than $\mathrm{N} 18,000-\mathrm{N} 23,000(52.0 \%)$ as income followed by those who earned between $\mathrm{N} 24,000-29$, 000 (21.1\%), N 30, 000- 35, $000(15.4 \%)$, and those that earn N35,000 - N40,000 (8.1\%), the least were those who earned more than $\mathrm{N} 40,000$.

Table 1. Socio- economic characteristics of the respondents

\begin{tabular}{llll}
\hline Variables & Frequency & Percentage & Mean \\
\hline Age (Years) & 17 & 13.8 & \\
$<20$ & 11 & 8.9 & 34.7 \\
$20-24$ & 37 & 30.1 & \\
$25-29$ & 24 & 19.5 & \\
$30-34$ & 23 & 18.7 & \\
$35-39$ & 11 & 8.9 & \\
$>39$ & & & \\
Sex & 63 & 51.2 & \\
Male & 60 & 48.8 & \\
Female & & & \\
Marital Status & 25 & 20.3 & \\
Single & 91 & 74.0 & \\
Married & 1 & 0.8 & \\
Divorced & 6 & 4.9 & \\
Widowed & & & \\
Educational level & 91 & 74.0 & \\
No formal Education & 23 & 18.7 & \\
Primary education & 8 & 6.5 & \\
Secondary education & 1 & 0.8 & \\
Tertiary education & & & \\
House hold size & 32 & 26.0 & \\
$2-5$ & 58 & 47.2 & \\
$6-9$ & 23 & 18.7 & \\
$10-13$ & 10 & 8.1 & \\
$>13$ & & 52.0 & \\
Income (\#) & 64 & 15.4 & \\
$18-23,000$ & 26 & 8.1 & \\
$24-29,000$ & 19 & & \\
$30-35,000$ & 10 & & \\
$35-40,00$ & & & \\
40,000 & & &
\end{tabular}

Dairy cattle production characteristics of the respondents are presented in Table 2. Results revealed the sources by which respondents got their cattle. These sources ranged from farm, Research Institutes and inheritance. The result revealed that more than half of the respondents got their cattle through inheritance (98.4\%); few respondents also got their cattle from Research Institutes $(0.8 \%)$ and farm $(0.8 \%)$. The result showed that main purpose of cattle production among the respondent was for income generation (91.1\%), while the least purpose of production of the 
respondent was for consumption (8.9\%). It was further shown that most of the respondents had between $16-20$ cattle (26.8\%), 22.8\% had greater than 49 cattle, $22.0 \%$ had $10-15$ cattle, $12.2 \%$ had $28-33$ cattle, $11.4 \%$ had $22-$ 27 cattle, while $4.9 \%$ had less than 10 cattle. Majority $(81.7 \%)$ of the respondents possess White Fulani cattle, $5.0 \%$ of the respondent reared Red Bororo and White Fulani, 4.2\% of the respondent owned White Fulani and Sokoto Gudhali.

Table 2. Dairy cattle production characteristics of the respondents

\begin{tabular}{|c|c|c|c|}
\hline Variables & Frequency & Percentage & Mean \\
\hline \multicolumn{4}{|l|}{ Sources of flock } \\
\hline Farm & 1 & 0.8 & \\
\hline Research institute & 1 & 0.8 & \\
\hline Inherited & 121 & 98.4 & \\
\hline \multicolumn{4}{|l|}{ Purpose of production } \\
\hline Income generation & 112 & 91.1 & \\
\hline Consumption & 11 & 8.9 & \\
\hline \multicolumn{4}{|l|}{ Herd size } \\
\hline Less than 10 & 6 & 4.9 & \\
\hline $10-15$ & 27 & 22.0 & \\
\hline $16-20$ & 33 & 26.8 & \\
\hline $22-27$ & 14 & 11.4 & 52 \\
\hline $28-33$ & 15 & 12.2 & \\
\hline More than 49 & 28 & 22.8 & \\
\hline \multicolumn{4}{|l|}{ Breeds } \\
\hline Red Bororo & 2 & 1.7 & \\
\hline White Fulani & 98 & 81.7 & \\
\hline Muturu & 2 & 1.7 & \\
\hline Red Bororo and white Fulani & 6 & 5.0 & \\
\hline White Fulani and Muturu & 1 & 0.8 & \\
\hline White Fulani and Sokoto gudali & 5 & 4.2 & \\
\hline White Fulani and Ndama & 1 & 0.8 & \\
\hline Red Bororo, white Fulani and Ndama & 5 & 4.2 & \\
\hline
\end{tabular}

The training needs of farmers in major areas of dairy cattle production is presented in Table 3 . Results revealed that almost all $(90 \%)$ of dairy cattle farmers perceived the training needs in Feeding as most important followed by Breeding and Health care with ranks VII, VI and V respectively. Majority of farmers perception was between "Most important" to "Important" for the areas of Housing and Management, Marketing and Finance as well as milk Preparation and Processing. However, Housing and Management, Marketing and Finance as well as milk Preparation and Processing were ranked III, IV and II respectively. Majority of the farmers perceived training needs in Biosecurity as least important which was ranked I.

Table 3. Training needs of farmers in major areas in dairy cattle production

\begin{tabular}{lllllll}
\hline Variables & MI (\%) & I (\%) & LI (\%) & TS & TWMS & Rank \\
\hline Breeding & $117(95.1)$ & $5(4.1)$ & $1(0.8)$ & 130 & 2.71 & VI \\
Feeding & $121(98.4)$ & $2(1.6)$ & - & 125 & 2.60 & VII \\
Healthcare & $113(91.9)$ & $10(8.1)$ & - & 131 & 2.73 & V \\
Housing and management & $50(40.7)$ & $54(43.9)$ & $19(15.4)$ & 215 & 4.53 & III \\
Marketing and finance & $49(39.8)$ & $71(57.7)$ & $3(2.4)$ & 200 & 4.30 & IV \\
Milking and milk processing & $44(35.8)$ & $67(54.5)$ & $12(9.7)$ & 211 & 4.53 & II \\
Biosecurity & $8(6.5)$ & $7(5.7)$ & $108(87.8)$ & 346 & 6.61 & I \\
\hline
\end{tabular}

MI- most important, I- important, LI- least important, TS- total score, TWMS- total weighted mean score. 
Presented in Table 4 are the training needs of farmers in different sub-areas of dairy cattle farming. Within the sub area of breeding, artificial insemination was ranked first, followed by estrous detection, heat detection and estrous cycle and time mating. With respect to feeding of dairy cattle; more than $40 \%$ of respondents perceived training as "needed" in all the five sub-areas of feeding. Majority (3.58\%) of the respondents recognized mineral mixture supplementation as "most needed" followed by balance ration and its composition (3.16\%) and feeding of different age group of the cattle $(2.40 \%)$ with rank I, II, and III respectively. Result on dairy cattle health care indicated that more than half of the respondents recognized training needs in common disease and preventive measures $(1.92 \%)$, vaccination (1.77\%), improved health management (1.51\%), ecto-parasites control (1.48\%), deworming (1.27\%) as "most needed" and were ranked as I, II, III, IV, and V.

In dairy development programme; artificial insemination service ranked first, followed by use of reproductive technologies, ration formulation, modern branding, improvement of grazing management, improved milk yield, creep feed calves when pasture quality is poor, improved dairy production, modern means of animal identification, pregnancy diagnosis, and cross breeding. In housing and management; construction of low cost scientific housing ranked first, followed by manure management (rank II) and record keeping (rank III). Furthermore, care and management of productive animals, identification and isolation of sick animals were ranked IV and V respectively. For marketing and finance, majority of respondent $(7.53 \%)$ determined training in banking and insurance as "most needed" followed by training needs in processing, sales of animal nutrition product, milking technology, storage of milk product, storage of milk, processing of milk for product with rank I, II, III, IV, V, VI and VII respectively.

Table 4. Training needs of farmers in different sub - areas of dairy cattle farming.

\begin{tabular}{lllllll}
\hline Variables & MN & N & LN & TS & TWMS & Rank \\
\hline Training Needs In Breeding (\%) & $121(98.4)$ & $2(1.6)$ & - & 125 & 2.66 & VIII \\
Selection of breeds & $75(61.0)$ & $45(36.6)$ & $3(2.4)$ & 174 & 4.00 & VI \\
Selection of breeding stock & $1(0.8)$ & $5(4.1)$ & $117(95.1)$ & 362 & 7.82 & I \\
Artificial insemination & $72(58.5)$ & $51(41.5)$ & - & 174 & 4.03 & V \\
Identification of infertility in cattle & $27(22.0)$ & $86(69.9)$ & $10(8.1)$ & 229 & 5.48 & II \\
Estrous detection & $74(60.2)$ & $45(36.6)$ & $4(3.3)$ & 176 & 4.07 & IV \\
Estrous cycle and time mating & - & $60(48.8)$ & $1(0.8)$ & 185 & 4.33 & III \\
Heat detection & $87(70.7)$ & $3(28.35)$ & $1(0.8)$ & 160 & 3.62 & VII \\
Pregnancy diagnosis & & & & & & \\
Training Needs In Feeding (\%) & $14(114)$ & $25(20.3)$ & $84(68.3)$ & 316 & 3.83 & II \\
Balance ration and its composition & $29(236)$ & $71(57.7)$ & $23(18.7)$ & 240 & 2.78 & III \\
Feeding of different age group & $29(236)$ & $79(64.2)$ & $15(12.2)$ & 232 & 2.63 & IV \\
Nutritional management of breed problem & $115(93.5)$ & $8(6.5)$ & - & 131 & 1.34 & V \\
Importance of clean feed and water & $2(1.6)$ & $7(5.7)$ & $114(92.7)$ & 358 & 4.41 & I \\
Mineral mixture supplementation & & & & & & \\
Training Need In Health Care \% & $120(97.6)$ & $2(1.6)$ & $1(0.8)$ & 127 & 2.00 & V \\
Deworming & $80(65.0)$ & $32(26.0)$ & $11(8.9)$ & 177 & 2.69 & II \\
Vaccination & $99(80.5)$ & $23(18.7)$ & $1(0.8)$ & 148 & 2.31 & IV \\
Ectoparasite control & $55(44.7)$ & $64(52.0)$ & $4(3.2)$ & 192 & 3.00 & I \\
Common disease and preventive measures & $96(78.0)$ & $26(21.1)$ & $1(0.8)$ & 151 & 4.63 & III \\
Improved health management & & & & & & \\
Dairy development programme & $85(69.1)$ & $31(25.2)$ & $7(5.7)$ & 168 & 5.22 & IX \\
Modern means of animal identification & $99(80.5)$ & $23(18.7)$ & $1(0.8)$ & 148 & 4.44 & XI \\
Cross breeding to improve quality cattle & $2(1.6)$ & $6(4.9)$ & $115(93.5)$ & 359 & 11.13 & I \\
Artificial insemination service & $63(51.2)$ & $60(48.8)$ & & 183 & 5.82 & VI \\
Improved milk hygiene & $48(39.0)$ & $54(43.9)$ & $21(17.1)$ & 282 & 8.99 & III \\
Ration formulation & $76(61.8)$ & $46(37.4)$ & $1(0.8)$ & 171 & 5.35 & VII \\
Creep feed calves & $72(58.5)$ & $45(36.6)$ & $6(4.9)$ & 168 & 5.27 & VIII \\
Improved diary production & & & & &
\end{tabular}




\begin{tabular}{lllllll} 
Uses of reproductive technologies & $8(6.5)$ & $32(26.0)$ & $83(67.5)$ & 321 & 10.17 & II \\
Pregnancy diagnosis & $63(51.2)$ & $57(46.3)$ & $17(13.8)$ & 178 & 4.97 & X \\
Improvement of grazing management & $67(54.5)$ & $52(42.3)$ & $4(3.3)$ & 183 & 5.83 & V \\
Modern branding & $64(52.0)$ & $47(38.2)$ & $12(9.8)$ & 194 & 6.20 & IV \\
Training Needs In Housing And Management & & & & & \\
Construction of low cost scientific housing & $8(6.5)$ & $35(28.5)$ & $80(65.0)$ & 318 & 4.01 & I \\
Identification and isolation of sick animal & $73(59.3)$ & $43(35.0)$ & $7(5.7)$ & 180 & 1.99 & V \\
Record keeping & $38(30.9)$ & $34(29.3)$ & $49(9.8)$ & 255 & 3.10 & III \\
Manure management & $7(5.7)$ & $50(40.7)$ & $64(52.0)$ & 299 & 3.85 & II \\
Care and management of productive animal. & $63(51.2)$ & $57(46.3)$ & $17(13.8)$ & 186 & 2.05 & IV \\
Training Needs In Marketing And Finance (\%) & & & & & \\
Sales of animal nutritionist product. & $57(46.3)$ & $49(39.8)$ & $17(13.8)$ & 197 & 3.44 & III \\
Banking and insurance & $63(51.2)$ & $49(39.8)$ & $11(8.9)$ & 246 & 7.53 & I \\
Training needs in processing & $11(8.9)$ & $111(90.2)$ & $1(0.8)$ & 238 & 4.35 & II \\
Milking technology & $54(43.9)$ & $62(50.4)$ & $7(5.7)$ & 199 & 3.43 & IV \\
Processing of milk for product & $69(56.1)$ & $45(36.6)$ & $9(7.3)$ & 186 & 3.13 & VII \\
Storage of milk & $63(51.2)$ & $49(39.8)$ & $11(8.9)$ & 194 & 3.29 & VI \\
Storage of milk product. & $67(54.5)$ & $35(28.5)$ & $21(17.1)$ & 200 & 3.36 & V \\
\hline
\end{tabular}

MN- Most needed, N-Needed, LN- least needed, TS- Total Score, TWMS-Total Weighed Mean Score.

Table 5 shows the training needs index of dairy cattle farmers. The training index in dairy farming indicated that almost all $(91.8 \%)$ of the farmers needed to be trained more on dairy cattle production and management while few $(8.4 \%)$ of the respondents had low level of training needs.

Table 5. Training needs index of dairy cattle farmers

\begin{tabular}{lll}
\hline Training need index $(\%)$ & Frequency & Percentage \\
\hline Low $(<33.34-66.66)$ & 10 & 8.4 \\
High $(>66.67)$ & 133 & 91.8 \\
\hline
\end{tabular}

Table 6 shows factors influencing training needs of dairy cattle production. Results revealed that age, source of flock inflow, purpose of production, flock size and breeds of cattle were significant $(\mathrm{p}>0.05)$ factors influencing training needs of dairy cattle production of the respondent, while sex, marital status, religion, household size and income were not significant $(\mathrm{p}<0.05)$ factors influencing training needs of dairy cattle production of the respondents. Also age, sex, marital status, religion, education level, source of flock inflow, purpose of production and breeds of cattle had positive direct effect on training needs of dairy cattle production of the respondents while occupation, household size, income had negative effect indirect effect on training needs of dairy cattle production of the respondents. The $\mathrm{R}^{2}$ was 0.511

Table 6. Factors influencing training needs of dairy cattle production of the respondent.

\begin{tabular}{lllll}
\hline Variables & B & Std. Error & t-value & p-value \\
\hline Age & 1.576 & 1.020 & 1.545 & 0.125 \\
Sex & 0.909 & 1.450 & 0.371 & 0.711 \\
Marital status & 1.377 & 2.195 & 0.627 & 0.532 \\
Occupation & -1.343 & 1.739 & -0.772 & 0.442 \\
Religion & 5.776 & 10.444 & 0.553 & 0.581 \\
Educational level & 2.976 & 1.534 & 1.942 & 0.055
\end{tabular}




\begin{tabular}{lllll} 
Household size & -2.291 & 1.510 & -1.517 & 0.132 \\
Income & -0.5947 & 1.347 & -0.435 & 0.664 \\
Source of flock in flow & 5.947 & 3.547 & 1.676 & 0.097 \\
Purpose of production & 0.036 & 1.209 & 0.030 & 0.976 \\
Flock size & -0.416 & 1.112 & -0.374 & 0.709 \\
Breeds of cattle & 6.023 & 7.325 & 0.822 & 0.413 \\
\hline
\end{tabular}

\section{Discussion}

Training needs among dairy farmers in Oyo state, Nigeria were assessed in this study. Result of age of respondents implies that majority of the respondent were still in their economically active ages. This agrees with the report of Popoola et al (2017) and it is an indication that agricultural production, particularly livestock production is a profession that is practiced by people of different age groups. Majority of the respondents were male, this is due to the fact that there is gender dimension to cattle production in Nigeria such that Nigerian pastoralists who are majorly Fulani tribe believe that large animals like cattle are can only be handled by men while small animals like sheep, goat, chicken are meant to be managed by women. Most of them were married; this is expected with result obtained for their age. The level of education of the respondents implies that majority of them cannot read and write; this may hinder better communication as well as adoption of innovations as reported by Asanwana, (2001); Popoola et al., (2017). Household size is an important variable that determines the total household food requirement and thus, affect per capita food consumption and household food security. The result of household size of respondents showed that majority of the respondents had household size between $6-9$ members and the mean household size was 17. This result agrees with result of Adebisi et al. (2020) who also reported higher high members as the modal family size among households. The result further revealed that majority $(52.0 \%)$ of the respondents earned more than $\mathrm{N} 18,000-\mathrm{N} 23,000(52.0 \%)$ as income followed by those who earned between $\mathrm{N} 24,000-29,000(21.1 \%), \mathrm{N} 30,000-35,000(15.4 \%)$, and those that earn N35,000 - N40,000 (8.1\%), the least were those who earned more than N40,000. Differences in the income generated could be related to number of animals (herd size) possess by individuals.

Respondents obtained their cattle from different sources, these sources ranged from farm, research institute and inheritance. More than half of the respondents got their cattle through inheritance which implies that that cattle production is a means of lineage and succession business among the respondents who are largely Fulani pastoralists. The respondents raise their cattle for various purposes which range from income generation, meat production, milk production, consumption and as socio-cultural status; result of this study revealed that majority of respondents raised their cattle primarily for income generation. It was further shown that most of the respondents had between 16 - 20 cattle, followed by those who have more than 49 cattle; this implies that the difference in the number of cattle possess by individuals could be responsible for the differences in the income generated by the respondents. White Fulani is the breed of cattle mostly possessed by the respondents; this may because White Fulani is a cattle breed raised for dual purpose (milk and beef).

The training needs of farmers in major areas of dairy cattle production indicated their areas of priority in terms of training. Result revealed that majority of the farmers' perception was "most important" for areas of breeding, feeding and healthcare, while their perception for areas like housing and management, marketing and finance, milking and milk processing were between "most important" and "important". However, the perception of most of the dairy farmers on biosecurity was "least important". The result obtained for training needs of farmers in areas of Feeding, Breeding and Healthcare disagreed with the report of Tekale et al. (2013) who ranked Healthcare, Feeding and Marketing as I, II, and III respectively. In a study conducted on goat farmers, Mohan et al. (2006) reported similar findings.

The training needs of farmers in different sub-areas of dairy cattle farming was assessed which were determined in major areas of production such a s breeding, feeding, healthcare, dairy development programme, housing and management, marketing and finance. Within the sub area of breeding, artificial insemination was ranked first, followed by estrous detection, heat detection and estrous cycle and time mating. Artificial insemination was ranked first among the sub-areas where the training was needed because of inadequate technical know-how among the farmers. Result obtained from the respondents on sub-areas of dairy cattle healthcare indicated that respondent really needed training in all aspects of healthcare of their animals. In a similar study on small ruminants, Chah et 
al., (2013) reported that majority of the farmers perceived training needs on common disease and preventive measures were the most needed. Respondents indicated high training needs in improved and assisted reproductive technologies of cattle production so as to improve the qualities of their cattle.

The overall involvement index of respondents was used as an indication of extent training needs of dairy cattle farmers. The index scores of Balaraju et al, (2014) was adopted which was ranged and scored as follows: index scores of range $0-33.33 \%$ which implies low training needs by the farmers; $34.33-66.66 \%$ implies medium training needs by the farmers and greater than $66.66 \%$ implies high training needs by the respondents. The overall training index in dairy farming indicated that majority of the farmers needed to be trained more on dairy cattle production and management. Similar findings were reported by Tekale et al., (2013); Chauhan and Kshirsagar (2012).

Result of factors influencing training needs of dairy cattle production revealed positive regression coefficient for age, sex, marital status, religion, educational level, sources of cattle, and purpose of cattle production and breeds of cattle raised by respondents. This implies that as the values of any of these variables increase, the extent of training needs of the dairy farmers will also increase. However there were negative regression coefficient for household size, income and flock size. This implies that increase in any of these variables will lead to decrease in extent of training needs by the respondents. The $\mathrm{R}^{2}$ was 0.511 indicating that about $51.1 \%$ of the extent of training needs of respondents in dairy cattle production was explained by influence of their cattle production characteristics.

\section{Conclusion}

Based on the result of this study, it was concluded that breeding, feeding and health care were perceived as the "most needed" training by the respondents. Although, training need in marketing and finance, milk preparation and processing, as well as housing and management were also perceived as important. Furthermore age, sex, marital status, religion, education level, source of flock flow, purpose of production and breeds of cattle had a direct effect on training needs of the respondent while occupation, household, flock size, had an indirect effect on training need of the respondents. It is therefore recommended that there is need for establishment of famers' training Institute specifically for dairy production to assess the training needs of dairy farmers' holistically.

\section{References}

Abubakar, I. A., \& Garba, H. S. (2004). A Study of Traditional Methods for Control of Ticks in Sokoto State, Nigeria. Proceedings of the 29th Annual Conference of the Nigerian Society for Animal Production, 29, 8788 .

Adebisi, G. L., Popoola, M. A., Olaniyi, T. A., Aladegbaye, M. I., Aigbe, F. O., Owoade, S. A., Soyewo, I. E., \& Ayodele, V. A. (2020). Extent of Involvement of Women in Dairy Farming Activities in Oyo State, Nigeria. Agricultural Science, 2(1). https://doi.org/10.30560/as.v2n1p162

Adesina, A. A., \& Zinnah, M. E. (1993). Technology characteristics, farmers' perceptions and adoption decisions: A Tobit model application in Sierra Leon. Agricultural Economics Journal, 9, 297-311. https://doi.org/10.1111/j.1574-0862.1993.tb00276.x

Asanwana, V. A. (2001). Coping strategies for Enhanced Rural Household Food Security among Female Farmers in Akwalbom state, Nigeria. Ph.D Thesis submitted to Department of Agricultural Extension and Rural Development University of Ibadan, Ibadan.

Balaraju, B. L., Khandekar, P., Chander, M., Kumar, H., Dileep, K., \& Prakashkumar, R. (2004). Small ruminant farmers training needs in Karnataka as perceived by Farmers and Veterinarians. Asian J. Animal sci., 9, 5258.

Chah, J. M., Obi, U. P., \& Ndofor-Foleng, H. M. (2013). Management practices and perceived training needs of small ruminant farmers in Anambra State, Nigeria. African Journal of Agricultural Research, 8(22), 27132721.

Chauhan, N. M., \& Kshirsagar, S. M. (2012). Assessment of training needs of members of tribal women SHGs for agriculture development. Ind. Res. J.Ext. Edu. Special issue, Vol (III), 193198.

FAO (2011). Success and Failures with Animal Nutrition and Technologies in Developing Countries. FAO animal production and health proceedings. In proceeding of FAO electronic conference, 1-30 September, 2010, Zimbambwe. 39-47pp.

Food and Agriculture Organization (2010). Production Year Book, UN Publication Rome. (PVS_GapAnalysisReport-Nigeria.pdf (application/pdf object) (accessed on 23/3/2020). 
Imaita, I. G. (2013). Training as a factor influencing adoption of innovation along mango value chains Meru County, Kenya. International Journal Studies, 5(2), 24-35. https://doi.org/10.5539/ijms.v5n2p74

Khan, M. J., Peters, K. J., \& Uddin, M. M. (2009). Feeding strategy for improving dairy cattle productivity in smallholder farm Bangladesh. Bangladesh Journal of Animal Science, 38, 67-85. https://doi.org/10.3329/bjas.v38i1-2.9914

Mafimisebi, T. E., Oguntade, A. E., Fajeminsin, N. A., \& Ayelari, P. O. (2012). Local Knowledge and Socio Economic Determinants of Traditional Medicines' Utilization in Livestock Health Managements in South West Nigeria. Journal of Ethnobiology and Ethno medicine, 7(3), 26-38.

Malau-Aduli, A. E. O., Dim, N. I., Abubakar, B. Y., Ehoche, O. W., Lufadeju, E. A., \& Olaoshebikan, Y. R. (2009). "Dairy Performance of Friesian-Bunaji Crosses and their Growth to Yearling Age." Seminar paper presented at the National Animal Production Research Institute (NAPRI), Shika, Nigeria. Feb. 18th, 2009.

Mohan, B., Sagar, R. L., \& Singh, K. (2006). Study on evaluation of training needs of goat farmers. Indian J. Small Ruminants, 12(1), 21-25.

Murai, A. S., \& Singh, B. K. (2011). Differential adoption of scientific dairy farming practices and related constraints. Indian Research Extension Education, 11(2), 46-49.

National Population Commission. (NPC) Nigeria 2006. Census Report.

Njombe, A. P., Msanga, Y. N., \& Temba, A. E. (2010). Efforts to Increase Improved Dairy Cattle in Tanzania. In: Proceedings of stakeholders workshop (Ministry of Livestock and Fisheries Development); 23 November, 2010, Dar es Salaam, Tanzania. 102-114pp.

Odebode, S. O., \& Mungong, C. H. (2001). Poverty Alleviation Strategies of Rural households in Mezan Division, North West Province, Cameroon/ Moor Journal of Agricultural Research, 2(2), 179-185.

Odebode, S. O., \& Popoola, M. A. (2016). Comparative analysis of income generation from sheabutter production by rural women in Saki West and ATISBO Local Government Areas, Oyo state, Nigeria. Science and Engineering Perspectives, 11, 71-83.

Popoola, M. A., Adebisi, G. L., Osijinrin, O. E., Babarinde, G. T., Lawal, A. M., \& Kunuji, O. M. (2017). Determinant of backyard poultry production as strategy for food security among households in Ibadan Metropolis. Nigeria. Proceeding of 6th ASANNLAS Joint Annual Meeting. September 10-14, 2017. Abuja.

Rivera, S. F., Okike, I., Manyong, V., Williams, T. O., Kruska, R. L., \& Tarawali, S. A. (2004). Classification and description of the major farming systems incorporating ruminant livestock in West Africa. Sustainable croplivestock production in West Africa. Available at http://ilri.org/InfoServ/Webpub/fulldocs/SustainableCropLivestock/Pg087_122\%20Fernandez.pdf. Accessed 27/3/2020.

Somda, J., Kamuanga, M., \& Tollens, E. (2005). Characteristics and economic viability of milk production in the smallholder farming systems in The Gambia. Agricultural Systems, 85, 42-58. https://doi.org/10.1016/j.agsy.2004.07.011

Tekale, M., Deshmukh, D. S., Rathod, P., \& Sawant, M. (2013). Training needs of goat keepers in Maharashtra. Indian Res. J. Extn. Edu., 13(2), 67-71.

Thapa, G. B. (2003). Adoption of agroforestry in hills of Nepal. Agricultural Systems Journal, 72(3), 177-196. https://doi.org/10.1016/S0308-521X(01)00066-X

Tibi, K. N., \& Aphunu, A, (2010). Analysis of Cattle Market in Delta State: The Supply Determinants. African Journal of General Agriculture, 6(4), 199-203.

Yuan, X., Lee, H. S., \& Kim, S. Y. (2010). Present and Future of Internet Banking in China. Journal of Internet Banking and Commerce, 15(1), 678-683.

\section{Copyrights}

Copyright for this article is retained by the author(s), with first publication rights granted to the journal.

This is an open-access article distributed under the terms and conditions of the Creative Commons Attribution license (http://creativecommons.org/licenses/by/4.0/). 